\title{
PENGEMBANGAN MODUL TRIGONOMETRI BERCIRIKAN OPEN-ENDED PROBLEM
}

\author{
Agung Deddiliawan Ismail ${ }^{\mathrm{a}}$, Anis Farida Jamil ${ }^{\mathrm{b}}$, \\ Octavina Rizky Utami Putric \\ Program Studi Pendidikan Matematika FKIP Universitas Muhammadiyah Malang \\ Jalan Raya Tlogomas No. 246 Malang

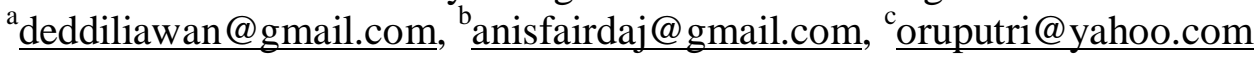

\begin{abstract}
ABSTRAK
Tujuan penelitian dan pengembangan ini adalah mengembangkan modul Trigonometri bercirikan open-ended problem yang dapat mendukung mahasiswa berpikir tingkat tinggi dengan kriteria kualitas valid, praktis, dan efektif. Penelitian dan pengembangan ini mengadaptasi model 4D oleh Thiagarajan, dkk yang terdiri dari tiga tahap, yaitu pendefinisian (define), perancangan (design), dan pengembangan (develop). Subjek uji coba dalam penelitian dan pengembangan ini adalah mahasiswa semester gasal 2016/2017. Modul, instrumen (lembar observasi aktivitas mahasiswa dan lembar angket respon mahasiswa), dan RPP yang dikembangkan telah memenuhi kriteria valid. Modul ini juga memenuhi kriteria praktis yang ditunjukkan oleh: (1) hasil pengamatan aktivitas mahasiswa yang memenuhi kategori sangat baik, dan (2) mahasiswa memberikan respon positif terhadap pembelajaran dengan menggunakan modul Trigonometri bercirikan open-ended problem. Modul ini memenuhi kriteria efektif yang ditunjukkan oleh peningkatan hasil tes observasi awal dan tes setelah uji coba modul.
\end{abstract}

Kata Kunci: pengembangan, modul trigonometri, open-ended problem

\begin{abstract}
The aim of this research and development (R\&D) is to develope Trigonometry module characterized with open-ended problem that can support high order thinking student with quality criteria: valid, practical, and effective. This R\&D adapted from 4D model by Thiagarajan et al consisting three stages: define, design, and develop. The subject of this R\&D is students of odd semester 2016/2017. Module, instrument (observation of students activities sheet dan quisioner), and Lesson Plan which developed have valid criteria. This module had practical criteria that showed by: (1) result of observation of students activities that have very good catagory, and (2) students have given positive responses for intructional using Trigonometry module characterized with open-ended problem. This module have effective criteria that showed by increase of pretest and postest score.
\end{abstract}

Key Words: development, trigonometri module, open-ended problem 


\section{Pendahuluan}

Reformasi pendidikan sains berasal dari pandangan konstruktivis. Reformasi ini berupa perubahan strategi pembelajaran teacher-centered menjadi student-centered (Miri, David, \& Uri, 2007). Student-centered menekankan pada kemandirian mahasiswa dalam berpikir dan belajar (Nohda, 2000). Dosen hanya bertindak sebagai pembimbing dalam pelaksanaan pembelajaran. Berkaitan dengan hal tersebut, mahasiswa dituntut untuk dapat berpikir tingkat tinggi. Berpikir tingkat tinggi ditandai dengan adanya kemampuan mahasiswa untuk memberikan gagasan-gagasan baru yang dapat diterapkan dalam pemecahan masalah (Krulik, Rudnick, \& Milou, 2003). Dalam hal ini, pemecahan masalah yang dimaksud adalah masalah dengan banyak jawaban yaitu open-ended problem.

Para peneliti di Institut Nasional Jepang melakukan penelitian pendidikan selama enam tahun untuk mengevaluasi berpikir tingkat tinggi matematis dengan menggunakan open-ended problem. Open-ended problem merupakan masalah terbuka yang memuat banyak jawaban, yang meliputi: (1) jawaban dengan banyak cara penyelesaian, (2) jawaban dengan banyak solusi penyelesaian, dan (3) dapat mengembangkan soal dari soal yang diberikan sebelumnya(Becker \& Shimada, 1997). Morgan, dkk. (2004: 22) juga menyatakan bahwa dalam pembelajaran matematika perlu menggunakan pendekatan open-ended untuk memberikan kesempatan berpikir dari sudut pandang berbeda.

Berdasarkan hasil observasi pada mahasiswa pendidikan matematika UMM semester I kelas B pada mata kuliah Trigonometri menunjukkan bahwa 23 dari 50 mahasiswa dapat memberikan banyak cara penyelesaian, 8 dari 50 mahasiswa dapat memberikan banyak solusi penyelesaian, dan 9 dari 50 mahasiswa dapat mengembangkan soal dari soal yang diberikan sebelumnya. Hal tersebut menunjukkan bahwa $46 \%$ mahasiswa dapat memberikan banyak cara untuk menyelesaikan masalah, 16\% mahasiswa dapat menyelesaikan masalah dengan memberikan banyak solusi, dan $18 \%$ mahasiswa dapat mengembangkan soal. Berdasarkan data tersebut disimpulkan bahwa mahasiswa belum dapat berpikir tingkat tinggi. Selain itu, selama ini belum ada buku referensi bercirikan open-ended problem pada mata kuliah Trigonometri di UMM yang dapat menjadikan mahasiswa belajar secara mandiri dan dapat mengembangkan berpikir tingkat tingginya. 
Berdasarkan latar belakang tersebut, dibutuhkan bahan ajar yang dapat mendukung mahasiswa untuk berpikir tingkat tinggi. Dalam penelitian ini bahan ajar yang akan dikembangkan adalah modul. Akbar (2013) mengatakan bahwa pembuatan modul ditujukan untuk keperluan belajar secara mandiri. Sehingga, dikembangkan modul bercirikan open-ended problem pada materi Trigonometri dengan harapan mahasiswa dapat belajar secara mandiri dan menumbuhkan kemampuan berpikir tingkat tinggi mereka. Karakteristik modul yang akan dikembangkan pada penelitian ini adalah memuat masalah open-ended dan menggunakan pendekatan Scientific Learning. Setiap subbab memuat $5 \mathrm{M}$ sesuai dengan sintaks Scientific Learning yaitu Mengamati, Menanya, Menggali Informasi, Mengasosiasi, dan Mengkomunikasikan. Pada tahap mengasosiasi, mahasiswa menyelesaikan suatu permasalahan openended secara berkelompok. Pengembangan modul bercirikan openended problem ini mengadaptasi model 4D oleh Thiagarajan dkk (1974). Prosedur pengembangan ini meliputi define, design, dan develop. Oleh karena itu, rumusan masalah dalam penelitian ini adalah bagaimana pengembangan modul Trigonometri bercirikan open-ended problem yang valid, praktis, dan efektif, serta tujuan penelitian ini adalah mengembangkan bahan ajar berupa modul Trigonometri bercirikan openended problem yang valid, praktis, dan efektif, sehingga dapat mendukung berpikir tingkat tinggi mahasiswa.

\section{Metode Penelitian}

Pengembangan modul bercirikan open-ended problem ini mengadaptasi model 4D (four D model) oleh Thiagarajan, dkk. (1974), meliputi: pendefinisian (define), perancangan (design), dan pengembangan (develop). Tahap pendefinisian meliputi analisis awal-akhir, analisis mahasiswa, analisis konsep, analisis tugas, dan perumusan tujuan pembelajaran. Tahap perancangan (design) terdiri dari penyusunan tes beracuan-kriteria, pemilihan format, dan desain awal. Sedangkan pada tahap pengembangan (develope) bertujuan untuk menghasilkan modul bercirikan open-ended problem materi trigonometri.

Data yang diperoleh pada penelitian dan pengembangan ini dianalisis dengan cara: (1) data kevalidan modul melalui perhitungan rata-rata hasil validasi dan masukan dari dua validator, (2) data kepraktisan modul melalui analisis hasil observasi kegiatan mahasiswa dalam 3 pertemuan dan angket respon mahasiswa, dan 3) data 
keefektifan modul melalui perhitungan skor tes setelah penggunaan modul.

\section{Hasil Penelitian dan Pembahasan}

Pengembangan Modul Trigonometri

\section{Bercirikan Open-Ended Problem}

Tahap pertama adalah pendefinisian (define). Tujuannya adalah menetapkan dan mendefinisikan syaratsyarat perancangan modul yang akan dikembangkan agar modul yang dihasilkan sesuai dengan kebutuhan. Langkah pertama pada tahap define adalah pengamatan secara cermat terhadap kondisi pembelajaran dan ketersediaan sumber belajar. Pembelajaran mata kuliah Trigonometri sudah menggunakan beragam model serta pendekatan, salah satu pendekatan yang sudah dilaksanakan adalah open-ended problem, namun belum maksimal karena ketersediaan sumber belajarnya belum mendukung. Sumber belajar yang tersedia belum memuat open-ended problem. Langkah kedua pada tahap ini adalah menelaah karakteristik mahasiswa semester I kelas B. Mahasiswa ini berasal dari beragam daerah sehingga memiliki pengalaman belajar dan pengetahuan yang beragam. Keberagaman ini dapat difasilitasi melalui pembelajaran dengan pendekatan open-ended, karena melalui pendekatan ini mahasiswa dapat memberikan gagasan yang beragam sesuai dengan pengetahuan masingmasing. Langkah selanjutnya adalah mengidentifikasi pokok materi Trigonometri dan menyusunnya dalam bentuk yang hirarki, meliputi: (1) Lingkaran Satuan, (2) Fungsi Trigonometri pada Sudut Khusus, dan (3) Fungsi Trigonometri pada Sudut Sebarang. Langkah keempat adalah menganalisis tugas-tugas yang diberikan pada mahasiswa. Tugas-tugas yang diberikan pada mahasiswa memuat indikator open-ended problem, yaitu menyelesaikan masalah dengan: (1) cara yang bervariasi, (2) jawaban yang bervariasi, dan (3) menyusun soal dan menyelesaikannya. Langkah kelima merupakan perumusan tujuan pembelajaran yaitu dengan merumuskan indikator-indikator pencapaian tujuan pembelajaran dengan menggunakan modul bercirikan open-ended problem.

Tahap selanjutnya adalah perancangan (desain). Langkah awal pada tahap ini adalah penyusunan instrumen penelitian yang digunakan untuk menghasilkan modul yang valid, praktis, dan efektif. Instrumen yang dibuat meliputi: (1) lembar validasi, (2) lembar observasi, (3) lembar tes, dan (4) angket respon mahasiswa. Langkah kedua adalah pemilihan format. Pemilihan format modul ini memuat langkah scientific learning antara lain 
Mengamati, Menanya, Menggali

Informasi, Mengasosiasi, dan

Mengkomunikasikan. Lanhkah tearkhir adalah desain awal. Pada Modul ini, langkah Mengamati, Menanya, Menggali Informasi, Mengasosiasi, dan Mengkomunikasikan berturut-turut dituliskan secara tersirat dengan kata "Tahukah anda?", “Ayo berpikir", "Mari gali pengetahuan!", "Yuk berdiskusi”, dan "Silahkan presentasikan". Pada "Tahukah anda" materi dikaitkan dengan masalah pada kehidupan sehari-hari sehingga mahasiswa memiliki gambaran kegunaan mempelajari materi pada bab tersebut. Pada "Ayo Berpikir" merangsang mahasiswa untuk memunculkan rasa ingin tahunya sehingga timbul pertanyaan mengenai materi yang akan dibahas. Pada "Mari gali pengetahuan" berisi penjelasan materi. Open-ended Problem terletak pada langkah "Yuk berdiskusi". Pada langkah "Silahkan Presentasikan", mahasiswa mempresentasikan hasil pekerjaannya. Kegiatan setelah membuat Modul Trigonometri Bercirikan Openended Problem adalah membuat RPP yang berguna untuk mempermudah uji coba modul. Pembuatan angket mahasiswa dan lembar observasi berguna untuk menentukan kepraktisan modul, sedangkan lembar tes berguna untuk menentukan kepraktisan modul.

\section{Kevalidan Modul Trigonometri Bercirikan Open-Ended Problem}

Modul trigonometri bercirikan open-ended problem yang dikembangkan telah memenuhi kriteria valid. Rata-rata hasil validasi modul mahasiswa adalah 2,83 . Hal ini menunjukkan modul yang dikembangkan memenuhi kriteria valid, yang berarti tidak perlu revisi dan dapat digunakan untuk uji coba.

\section{Kevalidan Instrumen yang Digunakan}

Pada penelitian pengembangan ini, instrumen yang digunakan antara lain: lembar tes, lembar observasi aktivitas mahasiswa, RPP, dan lembar angket respon mahasiswa. Instrumen tersebut divalidasi oleh validator ahli. Rata-rata hasil validasi lembar tes adalah 2,8. Hal ini menunjukkan lembar tes memenuhi kriteria valid yang berarti tidak perlu revisi dan dapat digunakan untuk uji coba. Hasil validasi lembar observasi adalah 2,87 yang memenuhi kriteria valid, sehingga tidak memerlukan revisi dan dapat digunakan dalam penelitian. Hasil validasi RPP adalah 2,78 yang menunjukkan RPP valid dapat diterapkan dalam pembelajaran. Sedangkan validasi angket mahasiswa memiliki rata-rata 2,93 yang berarti angket ini memenuhi kriteria valid dan dapat diujicobakan. 


\section{Kepraktisan Modul Trigonometri}

Bercirikan Open-Ended Problem

Modul yang dikembangkan telah memenuhi kriteria praktis. Hal ini dapat terlihat dari data yang diperoleh dari hasil observasi aktivitas mahasiswa dan hasil angket respon mahasiswa. Rata-rata hasil observasi aktivitas mahasiswa oleh 2 observer selama 3 pertemuan adalah 2,52 yang memenuhi kategori sangat baik. Mahasiswa memberikan respon positif pada pembelajaran dengan menggunakan modul Trigonometri bercirikan openended problem yang ditunjukkan oleh rata-rata hasil angket respon mahasiswa adalah 1,68. Berdasarkan hasil observasi aktivitas mahasiswa yang berkategori sangat baik dan respon positif dari mahasiswa, maka dapat disimpulkan bahwa modul ini memenuhi kriteria praktis.

\section{Keefektivan Modul Trigonometri} Bercirikan Open-Ended Problem

Modul Trigonometri bercirikan open-ended problem yang dikembangkan telah memenuhi kriteria efektif. Hal tersebut dapat terlihat dari adanya peningkatan nilai dari hasil tes pada observasi awal dengan hasil tes mahasiswa setelah pelaksanaan uji coba modul. Terdapat peningkatan $32 \%$ mahasiswa yang menjawab benar dalam menjawab masalah dengan cara bervariasi. Peningkatan mahasiswa yang menjawab benar dalam menjawab masalah dengan jawaban bervariasi sebesar $62 \%$. Sedangkan peningkatan mahasiswa dalam menyusun soal dengan mengubah masalah yang diberikan sebelumnya serta menyelesaikannya sebesar 44\%. Berdasarkan hal tersebut, terdapat peningkatan persentase mahasiswa yang menjawab benar untuk setiap indikator open-ended problem yang diberikan. Oleh karena itu, dapat disimpulkan bahwa modul yang dikembangkan memenuhi kriteria efektif.

\section{Kesimpulan}

Karakteristik modul yang dikembangkan memuat masalah openended dan menggunakan pendekatan Scientific Learning dengan sintaks yaitu Mengamati, Menanya, Menggali Informasi, Mengasosiasi, dan Mengkomunikasikan. Pada tahap mengasosiasi, diberikan permasalahan open-ended. Pengembangan modul bercirikan open-ended problem ini dilaksanakan sesuai prosedur pengembangan yang meliputi define, design, dan develop. Modul Trigonometri bercirikan open-ended problem ini telah memenuhi kriteria valid, praktis, dan efektif. 


\section{Ucapan terima Kasih}

Peneliti mengucapkan terima kasih kepada pihak-pihak yang telah membantu kegiatan penelitian ini, diantaranya kepada validator, observer, subjek uji coba, serta part timer. Pihakpihak tersebut telah banyak membantu sehingga penelitian ini berjalan lancar.

\section{Pustaka}

Akbar, Sa'dun. (2013). Instrumen Perangkat Pembelajaran. Bandung: PT Remaja Rosdakarya Offset.

Becker, J. P., \& Shimada, S. (1997). The Open-Ended Approach: A New Proposal for Teaching Mathematics. ERIC.

Krulik, S., Rudnick, J., \& Milou, E. 2003. Teaching Mathematics in Middle
School: A Practical Guide. Boston: Allyn and Bacon.

Miri, B., David, B.-C., \& Uri, Z. (2007). Purposely teaching for the promotion of higher-order thinking skills: A case of critical thinking. Research in Science Education, 37(4), 353-369.

Morgan, C., Watson, A. \& Tickly, C. 2004. Teaching School Subjects 11-19: Mathematics. London: Routledge Falmer.

Nohda, N. (2000). Teaching by OpenApproach Method in Japanese Mathematics Classroom.

Thiagarajan,S., Semmel, D.S., \& Semmel, M.I. 1974. Instructional Development for Training Teacher of Exceptional Children. Reston: Sourcebook. 
